Jurnal Riset Biologi dan Aplikasinya, Volume 2, Nomor 2, September 2020

Jurnal Riset Biologi dan Aplikasinya
https://journal.unesa.ac.id/index.php/risetbiologi

\title{
The Phenetic Relationship of Ferns (Polypodiaceae) at the Ascent of Cemoro Kandang, Mount Lawu
}

\author{
Hubungan Kekerabatan Tumbuhan Paku Famili Polypodiaceae \\ di Pendakian Cemoro Kandang, Gunung Lawu
}

Advend Sri Rizki Sianturi*

Science Education Department, Universitas Negeri Semarang

\begin{tabular}{l} 
Article History \\
\hline Received : 2 September 2020 \\
Approved : 24 September \\
2020 \\
Published : 30 September \\
2020
\end{tabular}

Keywords: relationship, fern, Polypodiaceae, sporophyte morphological

Kata Kunci: kekerabatan, tumbuhan paku, polypodiaceae, morfologi sporofit

\begin{abstract}
The fern is one of the highly diverse vascular plant species, which has a unique characteristic. The closely related at the family level because the genera within each family have some uniformity so that the relationship and groupings cannot be distinguished. One example of a diverse fern family is Polypodiaceae. Consequently, it is necessary to simplify the classification; one of them is through phenetic relationship analysis. This study aimed to analyze the phenetic relationship of the Polypodiaceae ferns in Climbing Cemoro, Mouth Lawu enclosure, Karangayar Regency, based on the similarity index on the dendogram. The data were collected using the exploration method and the sporophyte morphological characters were observed. The observations obtained 13 variations of characters. The relationship analysis was carried out with the hierarchical cluster program using SPSS 23. There were six species found from the Polypodiaceae family, there were including Belvisia mucronata, Goniophlebium sp, Lepisorus sp, Pyrrosia piloselloides, Crypsinus taeniatus and Drynaria sparsisora. The finding suggests that six species are divided into two clusters, the Group I consisting of Goniophlebium sp, Lepisorus sp, Lepisorus sp, and Pyrrosia pilloselloides with a similarity coefficient index of 53\% and Group II consisting of Drynaria sparsisora, Goniophlebium sp, and Pyrrosia piloselloides with a similarity index of $46 \%$.
\end{abstract}

\begin{abstract}
Abstrak
Tumbuhan paku salah satu spesies tumbuhan vaskular yang memiliki keragaman tinggi. Kedekatan kerabatan pada tingkat famili dikarenakan antara genus dalam tiap famili memiliki beberapa keseragaman, sehingga tidak bisa dibedakan pengelompokannya. Salah satu contoh famili tumbuhan paku yang memiliki keragaman adalah Polypodiaceae. Penelitian ini bertujuan untuk mendeskripsikan hubungan kekerabatan secara fenetik tumbuhan paku famili Polypodiaceae di Pendakian Cemoro Kandang Gunung Lawu, berdasarkan indeks kesamaan pada dendogram. Pengumpulan data dilakukan menggunakan metode eksplorasi dan dilakukan pengamatan karakter morfologi sporofit. Hasil penelitian diperoleh 13 macam karakter. Analisis hubungan kekerabatan dilakukan dengan program hierarchial cluster menggunakan SPSS 23. Terdapat enam spesies yang ditemukan darifamili Polypodiaceae di antaranya Belvisia mucronata, Goniophlebium sp, Lepisorus sp, Pyrrosia piloselloides, Crypsinus taeniatus dan Drynaria sparsisora. Hasil penelitian menunjukkan bahwa keenam spesies tersebut terbagi menjadi dua klaster, yaitu Kelompok I terdiri atas Goniophlebium sp, Lepisorus sp, dan Pyrrosia pilloselloides dengan indeks koefisien kesamaan 53\% dan Kelompok II terdiri atas Drynaria sparsisora, Goniophlebium sp, dan Pyrrosia piloselloides dengan indeks kesamaan $46 \%$.
\end{abstract}

How to cite: Sianturim A.S.R. (2020). The Phenetic Relationship of Several Species of Ferns in the Polypodiaceae Family Based on Morphological Characters on the Ascent of Cemoro Kandang, Mount Lawu. Jurnal Riset Biologi dan Aplikasinya, 2(2): 64-69. 


\section{INTRODUCTION}

Indonesia is one of the countries that has the highest biodiversity in the world, both plant and animal diversity. One of the species of plant division found in Indonesia is ferns (Pteridophyta). The number of Pteridophyta species in Indonesia was 2,197 species and the latest study results in the last 2019 showed that the Pteridophyta in Indonesia reached 1,611 taxa from 37 families (Nurchayati, 2007). This amount is obtained when using the classification basis used in the Herbarium Bogoriensa (Wijayanti et al., 2015).

The fern is a division that has corms, meaning that its body can differentiated into three main parts, namely roots, stems, and leaves. Besides, this plant also has a vessel/file system in the form of xylem and phloem, which is not found in moss. Roots in ferns are like fibers and the ends are protected by calyptra (root caps). The stems of most ferns are not visible because they are in the soil in the form of rhizomes/rhizomes (Holtum, 1959). Ferns have unique characteristics in sporophyte and gametophyte generation, which is mutually independent. One of the ferns' unique characteristics lies in the morphological character of the sporophyte, which is used as a determinant of ferns in terms of shape, size, location, and spores' types (Suryadi et al., 2020, Apriyanti et al., 2017). Ferns are very heterogeneous when viewed in terms of habitus and way of life. Based on the habit, there are a few species of ferns with small leaves and a very simple structure. On the others, there were large with leaves that could reach up to two or more with a complex structure. Based on the way of life, there are species of ferns that live on the ground (terrestrial), some live on other plants (epiphytes), and also water ferns (hygrophytes). Ferns tend to like shady places with a high degree of humidity and cannot stand it. in conditions with limited water availability.

There are five families of pteridophytes with the largest proportion included Polypodiaceae, Thelypteridaceae, Pteridaceae, Hymenophyllaceae, and Cyatheaceae families, which cover almost $50 \%$ of the total diversity (Tjitrosoepomo, 1993). This value has decreased significantly from the previous pteridophyte diversity data, considering that this time information on the status of scientific names is more widely available and the progress of taxonomic revisions is quite rapid. However, it should be noted that there are still many species richness or taxa under species that have not been revealed and recorded, both their identity and presence in the archipelago.

The diversity of ferns is very large in nature, so that ferns are one of the plants that cannot be separated from the effort to simplify the object of study. Ferns are the most primitive vascular plants than other vascular plants. The fern has gone through various stages of evolution from the Devonian to the present. However, research on the classification and relationship of Pteridophyta has not been widely carried out, however, only a few studies on fern relationship have been conducted (Nurchayati, 2007). Ferns play important roles in maintaining the forest ecosystem (Suryadi et al., 2020), therefore, it is required to improve conservation and inventory of relationship to prevent biodiversity extinction. Phenetic relationship is a pattern of relationship or total similarity between groups based on their certain characteristics from each group.

Ferns are often found in humid areas such as mountain areas. One of the habitat ferns is Mount Lawu, or Gunung Lawu, this mount massive compound stratovolcano, straddling the border between Central Java and East Java, Indonesia. Mount Lawu has an important function for the protection of natural resources and ecosystems. This area is a buffer zone that limits the distribution of dry-type ecosystems in eastern Java and wet-type ecosystems in western Java. The high diversity of ferns is caused by environmental factors where the elevation of the area increases, the soil condition changes. According to Krebs (1985), soil moisture affects the geographic distribution of most trees in mountain forests and affects the content/ availability of groundwater where the relationship with temperature can affect the balance of plant water. Other environmental factors that affect the growth of ferns are temperature, air humidity, soil $\mathrm{pH}$, and light intensity.

\section{MATERIALS AND METHODS}

This study was conducted in the Cemoro Kandang hiking trail, Mount Lawu, Karangayar Regency, Central Java Province. The Parameters used in the study were morphological characteristics of habitat, stems, roots, leaves, and sorus.

The steps of data collection were as follows. (a) The morphological observation of the species include habitat (the type of habitat), stem (color and fiddlehead; color, shape, and stipe characteristics; color and shape of the rachis surface), leaf (type, 
location, structure, shape, venation, and costa), root (rhizome and rhizoid) and sorus (location, shape, and color). (b) Designing observation table (table of Operational Taxonomy Unit) by providing numeric symbols. The description of Operational Taxonomy Unit feature can be described as number 0 if the feature does not have number 1 as well as if the observed characteristics are in that type. (c) Perform calculations using the SPSS program in the observation table. (d) The determination of the relationship between the ferns of the Polypodiaceae family was carried out by measuring the similarity or Similarity Index (IS) and measuring the dissimilarity or dissimilarity index (ID) using the following formula:

$$
(\mathrm{IS})=\frac{2(\Sigma C)}{(\Sigma A)+\left(\sum B\right)} x \mathbf{1 0 0} \%
$$

(Hasanuddin \& Fitriana, 2014)

$$
\begin{aligned}
& \text { Note: } \\
& \text { ID = Dissimilarity Index } \\
& \text { IS }=\text { Similarity Index } \\
& \sum \mathrm{C}=\text { Number of the same Characteristics in } \\
& \text { individuals being compared } \\
& \sum \mathrm{A}=\text { number of individual characteristics A } \\
& \sum \mathrm{B}=\text { number of individual characteristics } \mathrm{B}
\end{aligned}
$$

Analysis of sample data that has been identified in accordance with Operational Taxonomy Unit was then analyzed using Taxonomic Distance formula to identify the relationship, which will be presented in the form of dendogram.

The observed morphological characteristics of ferns consisted of several types (Table 1). The sporophyte morphological character data were analyzed using a phenetic approach using the SPSS 23 Hierarcial Cluster dendogram program.

\section{RESULTS AND DISCUSSION}

The ferns was found and identified on Mount Lawu, the Cemoro Kandang hiking trail consists of 15 families including Gleiheniaceae, Woodsiaceae, Vittariaceae, Pteridiaceae, Nepheolepidaceae, Davalliaceae, Polypodiaceae, Marattiaceae, Lycopodiaceae, Dennstaedtiaceae, Dipteridaceae, Blechnaceae, Adiantacea, distributed in 33 species.

\begin{tabular}{|c|c|c|}
\hline No. & Character & Character code \\
\hline 1. & Habitat & Terrestrial (0), Epiphytic (1) \\
\hline 2. & Leaf & Single or pinnatifid (0), leaves 1 - pinnate $(1)$ \\
\hline 3. & Leaf margins & Flat (0), Pinnatifid (1) \\
\hline 4. & Build leaves & Lanset (0), elliptical-lancet (1) \\
\hline 5 . & Leaf shape & monomorphic $(0)$, dimorphic $(1)$ \\
\hline 6. & Rhizome & Upright (0), Creeping (1) \\
\hline 7. & Sorus & Small circle, near midrib (0), linear, marginal (1) \\
\hline 8. & Sorus location & $\begin{array}{l}\text { On the lower surface of the leaf, Varies (0), at the tip of the fertile leaf } \\
\text { spike (1), }\end{array}$ \\
\hline 9. & Sorus form & $\begin{array}{l}\text { Sorus linear, ablique, extending from midrib to margin }(0) \text {, sorus round, } \\
\text { forming a single row to several irregular rows }(1)\end{array}$ \\
\hline 10. & Sorus size & $\begin{array}{l}\text { Sorus until } 2 / 3 \text { of the leaves are towards the base }(0) \text {, sorus until } 1 / 2- \\
1 / 3 \text { towards the apex }(1)\end{array}$ \\
\hline 11. & Sorus diameter & Less than $0.1 \mathrm{~cm}(0)$, less than $0.2 \mathrm{~cm}(1)$ \\
\hline 12. & Sorus arrangement & Forming irregular, rather dense $(0)$, regular sorus $(1)$ \\
\hline 13. & Leaf species & $\begin{array}{l}\text { There are } 1 \text { species, leaves foliage }(0) \text {, there are } 2 \text { species of leaves, nest } \\
\text { leaves and foliage leaves }(1)\end{array}$ \\
\hline
\end{tabular}
The highest number of species found were in the Polypodiaceae family as many as 6 species. The relationship of several species of ferns in the Polypodiaceae family of other species has been previously studied at the Purwodadi Botanical Garden, Pasuruan.

Table 1. List of characters for phenetic analysis of Family Polypodiaceae 
The results showed that Adiantum caudatum was related to Nephrolpeis falcate with a similarity coefficient of $66.7 \%$ (Nurchayati, 2016). The results of sporophyte morphological observations of the sporophyte family of the Polypodiaceae Gunung Lawu climbing Cemoro Kandang were obtained as follows:

\section{Belvisia mucronata}

Epiphytic, short creeping rhizomes, growing 46 tightly, dense scaly, $3 \mathrm{~cm}$ long stype, linear lanceolata leaves, single, sterile leaves $15-18 \mathrm{~cm}$ long, $2 \mathrm{~cm}$ wide, shrinking at the base and tip, curling at the margins, narrowing at junction with fertile leaf, short winged towards the stipe, veins generally not clear, midrib visible on both surfaces, sorus at apical fertile leaf, linear shape with tapered tip, $12 \mathrm{~cm}$ long, $0.4 \mathrm{~cm}$ wide, sporangium covering the abaxial leaves except midrib (Figure 1.A).

\section{Crypsinus taeniatus}

Terrestrial, creeping rhizome, dense scaly, scales taper slowly to the apex, pale brown, slightly dark in the middle, flat edges slightly jagged, stipe 15-30 cm; pinnate leaf, $30-40 \mathrm{~cm}$ long, with 7-10 pairs of pinna, narrow ellipse shape, long apex acuminate, thickened edges, with short serrations of each main vein, round sorus, forming a single row between midrib and pina edge, slightly raised adaxial, a diameter of $2-3 \mathrm{~mm}$. The sporangium is reddish brown in color (Figure 1.B).

\section{Drynaria sparsisora}

Epiphyte, erect rhizome, short scaly, tapering from the round base, stiff, deciduous after growing leaves (base leaves / nest leaves and foliage leaves), dense, short scaly, shrinking, from apex to ovate, dimorphic leaves, foliage, pinnatifid, length 60-70 $\mathrm{cm}$ including stipe, sorus generally small, in regular rows, always with irregular space between rows (Figure 1.C).

\section{Goniophlebium sp}

Epiphyte, creeping rhizome, white chalky surface, scaly young part, light brown scales, slightly jagged edges, pinnate leaves, $0.7 \mathrm{~cm}$ in diameter, brown, slightly scaly stipe and rachis. Sorus forms a single row on each side of the midrib, between the veinlets, the hollow, shallow, yellowish sporangium (Figure 1.D).

\section{Lepisorus sp}

Epiphytic, rhizome spreads long, grows 2 rows of leaves, $1 \mathrm{~cm}$ apart, dense scaly, $4-6 \mathrm{~cm}$ long, wingless, fertile leaf type is longer than fertile leaves, dark brown scaly at the base, single lamina, 10 - 12 long $\mathrm{cm}, 2 \mathrm{~cm}$ wide, sorus forms a single row at each midrib, round, $2 \mathrm{~mm}$ in diameter, brown sinks in the cavity, adaxial embossed (Figure 1.E).

\section{Pyrrosia pillosellides}

Epiphytes, creeping rhizomes, small scales with long hairy edges, no stype on sterile leaves, $1 \mathrm{~cm}$ long fertile leaves, 3-6 cm long sterile leaves, and 1 cm wide, close to blat, sometimes elliptic widened, crossed, tapers slowly to base, wide round apex, very fleshy texture, smooth surface, scattered stellate hairs, clear midrib on half of the leaves from the base, 3-6 cm long and $0.8 \mathrm{~cm}$ wide fertile leaves, tapers slowly to the base, wide round apex, very fleshy texture, sorus forms a wide band at the marginal, present in a semicircle from the apex to almost near the base (Figure 1.F).

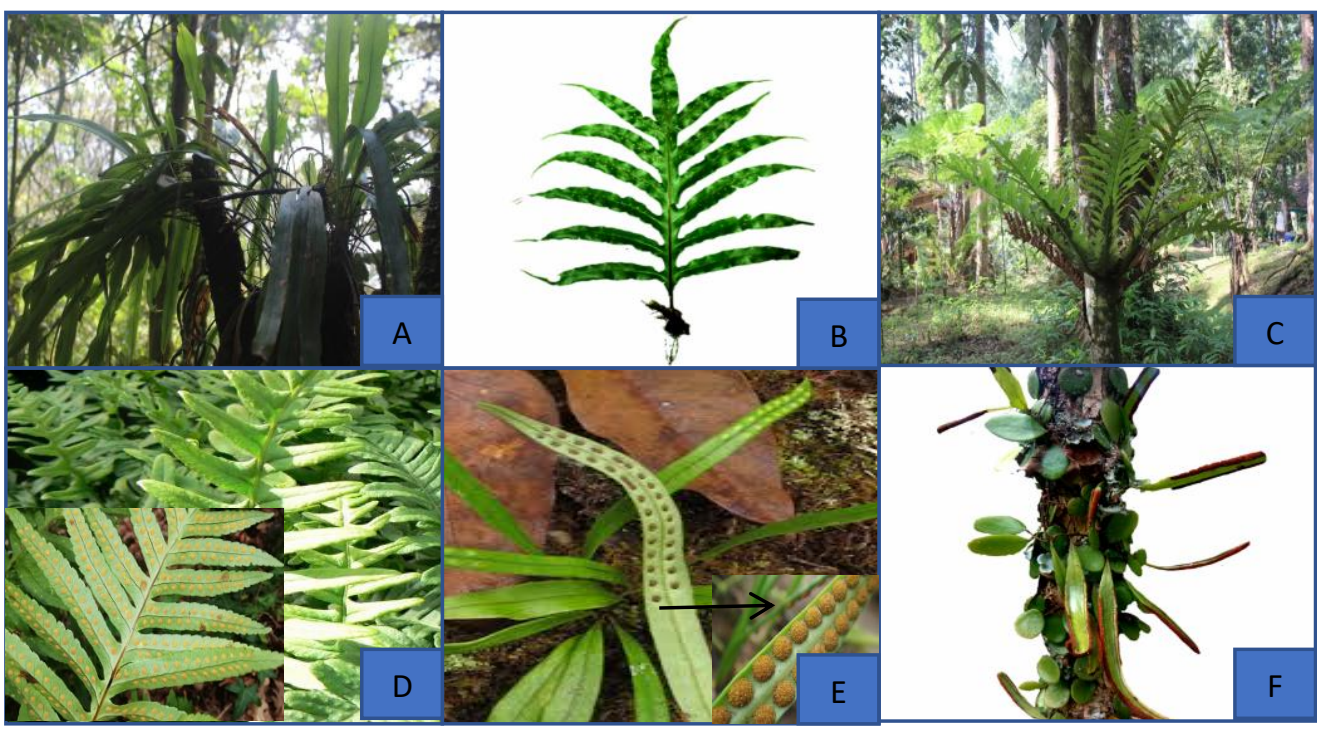

Figure 1. A) Belvisia mucronata; B) Crypsinus taeniatus; C) Drynaria sparsisora; D) Goniophelebium sp; E) Lepisorus sp; F) Pyrrosia pillosellides 


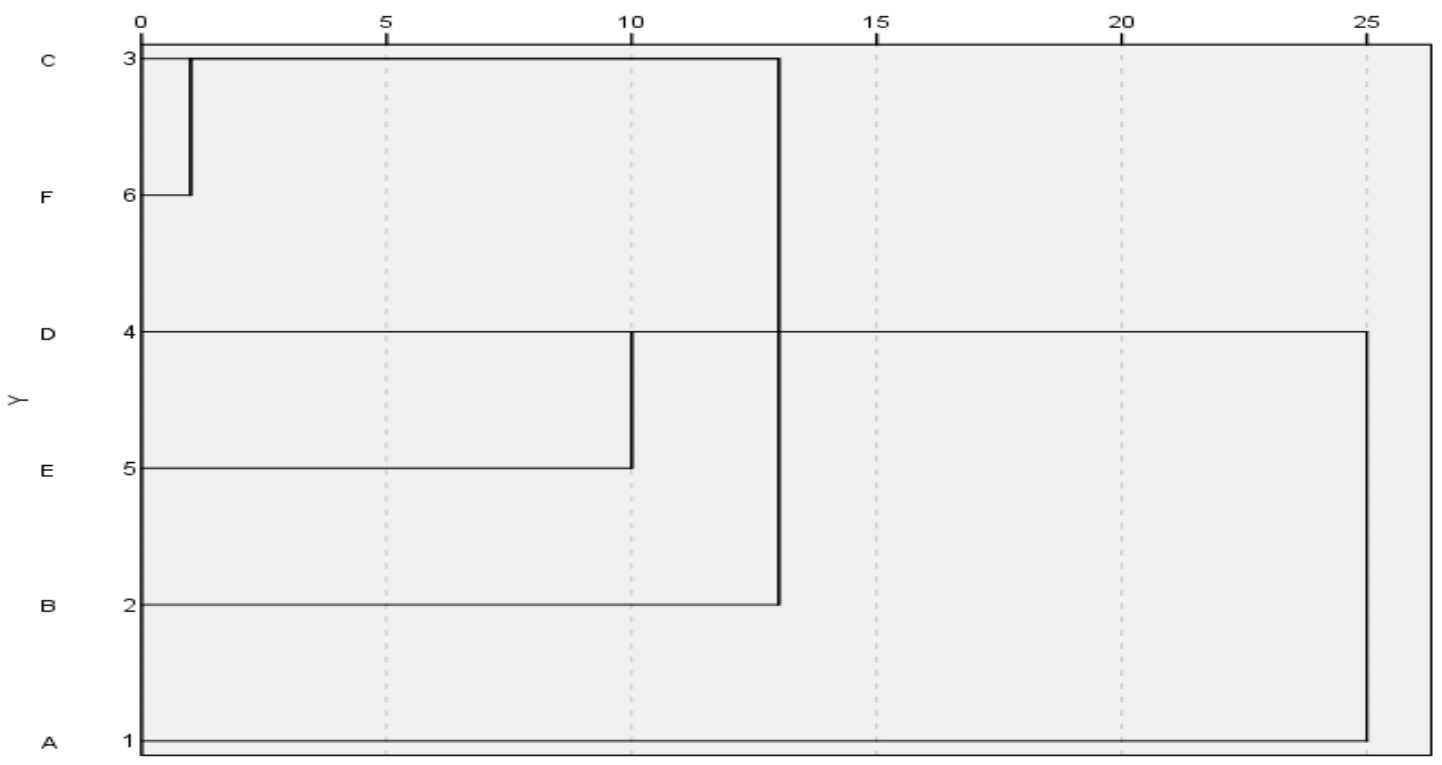

Figure 2. Dendogram of six species of ferns, Family Polypodiaceae. A = Belvisia mucronata $; \mathrm{B}=$ Crypsinus taeniatus; $\mathrm{C}$ = Drynaria sparsisora $; \mathrm{D}=$ Goniophlebium $\mathrm{sp} ; \mathrm{E}=$ Lepisorus sp; $\mathrm{F}=$ Pyrrosia pillosellides

The results of the dendogram construction using 13 morphological features showed that the six species of ferns found were divided into two main clusters, namely cluster I consists of Goniophlebium sp, Lepisorus sp, and Pyrrosia and cluster II consists of Drynaria sparsisora, Goniophlebium sp, and Pyrrosia piloselloides. The following is the dendogram of the results of cluster analysis of 6 plant species that have been analyzed for their morphological characterization.

Based on the calculation of the Similarity Index, Goniophlebium sp is closely related to Lepisorus sp at a similarity coefficient of $53 \%$ and also Lepisorus sp is closely related to Pyrrosia piloselloides at a coefficient of $53 \%$. Drynaria sparsisora and Goniophlebium sp are closely related to Pyrrosia piloselloides with a similarity coefficient of $46 \%$. Then followed by Crypsinus taeniatus which is related to Goniophlebium sp, Lepisorus and Pyrrosia piloselloides with a similarity index of $38 \%$. Belvisia mucronata is closely related to Lepisorus sp and Pyrrosia. In addition, the influence of diversity in a type is caused by two factors, namely the environment and traits inherited by genetics (Chao \& Huang, 2018).

Group I consisted of Goniophlebium sp, Lepisorus sp, and Pyrrosia pillosellides. Those that are united based on the same habitat are epiphytes, creeping rhizomes, and have scales on the rhizomes. Group II consisted of Drynaria sparsisora, Goniophlebium sp, and Pyrrosia piloselloides which were united by habitat type characteristics, rhizomes and spore arrangement that were single rows in each midrib sequence.

In accordance with the opinion of Radford (1986), the closely relationship can be seen by the number of similarities in characters or characteristics, so they have a kinship with a greater similarity coefficient, hence the relationship is closer. This is same opinion with (Vasco et al., 2013) opinion that the classification is based on the characters' correlation so that two plants that have similar characteristics are considered closely relationship than two plants that have few characters in common. Based on the dendogram above, a grouping system can also be made among species in the Polypodiaceae family based on their relationship. While, Apriyanti et al. (2017) stated that more similarities of characteristics they have, the smaller the number of taxonomic distance value based on plant combinations. Besides that, it was concluded that the grouping based on the percentage of similarity of qualitative and quantitative characters observed produce a picture of the position of each accession in a dendrogram, generic distance values as well as showing the closeness of relationships or the similarity of characters between accessions.

\section{REFERENCES}

Apriyanti, N., Jaya Santri, D., \& Madang, K. (2017). Identifikasi Tumbuhan Paku (Pteridophyta) dan Kekerabatannya di Kawasan Air Tejun Curup Tenang Bedegung Kecamatan Tanjung Agung Kabupaten Muara Enim. Jurnal Pembelajaran Biologi, 5(2), 113- 
69 | Sianturi; The Phenetic Relationship of Several Species of Ferns in the Polypodiaceae

116. https://doi.org/Identifikasi Tumbuhan Paku (Pteridophyta) dan Kekerabatannya di Kawasan wisata air terjun curup tenang bedegung kecamatan tanjung agung kabupate Muara Enim.

Chao, Y. S., \& Huang, Y. M. (2018). Spore morphology and its systematic implication in Pteris (Pteridaceae). PLoS ONE, 13(11), 1-22. https://doi.org/10.1371/journal.pone.0207712.

Fitriana, H. \&. (2014). Hubungan Kekerabatan Fenetik 12 Spesies Anggota Familia Asteraceae. Jurnal EduBio Tropika, 2(2), 202-205. http://www.jurnal.unsyiah.ac.id/JET/article/view/5 260/4406.

Holttum, RE 1959. Flora Melesiana, series II Pteridophyta. Fern and Allies. Neterland: New York Botanical Garden. https://doi.org/10.5962/bhl.title.41457

Krebs. 1978. Ecology. The Experimental Analysis of Distribution and Abudance. London: Harper and Row Publisher.

Radford, AE 1986. Frundamnetal of Plant Systematic. Harper and Row Publisher Inc. New York.

Nurchayati, N. (2007). Hubungan Kekerabatan Beberapa Spesies Tumbuhan Paku Familia Polypodiaceae dari Karakter Morfologi Sporofit dan Gametofit. Jurnal Ilmiah PROGRESSIF, 7(19), 9-18. https://www.google.com/url? sa =t\&rct=j\&q=\&esrc= s\&source $=$ web\&cd $=6 \&$ cad $=$ rja\&uact $=8 \&$ ved $=0$ CEM QFjAF\&url=http://untagbanyuwangi.ac.id/attachments/article/339/Hubunga n Kekerabatan Beberapa Spesies Tumbuhan Paku .pdf\&ei=C1UJVdDhKsyOuATf4GQAQ\&usg=AFQjC

Suryadi, Muhibuddin, Hasanuddin, Samingan, \& Nurmaliah, C. (2020). Phenetic kinship of eight ferns from Filicinae class based on morphological and anatomical characteristic. Journal of Physics: Conference Series, 1460(1), O-6. https://doi.org/10.1088/17426596/1460/1/012077.

Tjitrosoepomo, G. 1993. General Taxonomy (Basic Plant Taxonomy). Yogyakarta: Gadjah mada University Press.

Vasco, A., Moran, R. C., \& Ambrose, B. A. (2013). The evolution, morphology, and development of fern leaves. Frontiers in Plant Science, 4(SEP), 1-16. https://doi.org/10.3389/fpls.2013.00345.

Wijayanti, L.,Mahmudati, L., Prihanta, W. (2015). Studi Kekerabatan Fenetik Genus Pteris Dengan Metode Taksimetri. Prosiding Seminar Nasional Pendidikan Biologi 2015, Yang Diselenggarakan Oleh Pendidikan Biologi FKIP Universitas Muhhamadiyah Malang, 1-10. https://pdfs.semanticscholar.org/faec/bdf4ebb723c96 b6 146c4195339d179d2488b.pdf. 